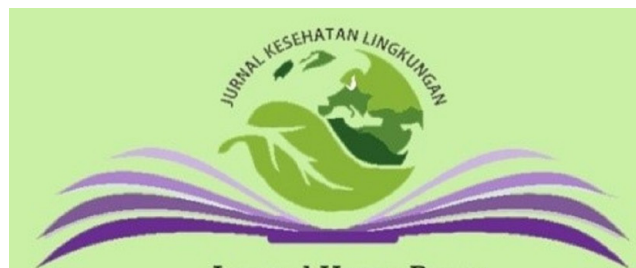

Journal Home Page:

https://e-journal.unair.ac.id/JKL

\section{Jurnal Kesehatan Lingkungan}

Vol. 13 No. 4

DOI: $10.20473 /$ jkl.v13i4.2021.193-198

ISSN: 1829 - 7285

E-ISSN: 2040 - 881X

\title{
RISK FACTORS OF ANTHRAX TRANSMISSION IN PACITAN REGENCY
}

Yudied Agung Mirasa ${ }^{1,2 *}$, Eko Winarti ${ }^{3}$, Adelita Setiawan ${ }^{4}$, Olievia Rachma Akhsani ${ }^{5}$

${ }^{1}$ Technical Centre for Environmental Health and Disease Control, Surabaya 60175, Indonesia.

${ }^{2}$ Department of Nursing, Faculty of Health Sciences,

Universitas Kadiri, Kediri 64115, Indonesia.

${ }^{3}$ Department of Midwifery, Faculty of Health Sciences,

Universitas Kadiri, Kediri 64115, Indonesia.

${ }^{4}$ Department of Epidemiology, Faculty of Public Health,

Universitas Airlangga, Surabaya 60115, Indonesia.

${ }^{5}$ Department of Environmental Health, Faculty of Public

Health, Universitas Airlangga, Surabaya 60115, Indonesia.

\section{Corresponding Author:}

*)ymirasa@gmail.com

\section{Article Info}

Submitted : 6 June 2021

In reviewed $\quad: 18$ June 2021

Accepted : : 12 July 2021

Available Online $\quad: 31$ October 2021

Keywords : Anthrax, Endemic areas, Risk

factors

Published by Fakultas Kesehatan Masyarakat

Universitas Airlangga

\begin{abstract}
Introduction: Anthrax was a zoonotic disease caused by the bacterium Bacillus anthracis in several regions of Indonesia. Transmission of anthrax in animals and humans occurred by direct contact with anthrax spores present in meat, soil, or plants. This study aimed to analyse the risk factors and recommend preventive action for anthrax transmission. Methods: This research used a descriptiveanalytic study to describing cases based on the case definition, primary data, and secondary data. The primary data were collected from the field observations and interviews with farmers and people in the community. The secondary data were obtained from the Pacitan District Health Office and Surabaya Technical Centre for Environmental Health and Disease Control. Data analysis of this study applied content analysis techniques that describe the actual situation of the community. Results and Discussion: Risk factors for anthrax transmission in Pacitan Regency included livestock traffic from endemic anthrax areas and lacked public knowledge about anthrax disease, rainfall, and topography. Conclusion: Anthrax disease control measurements include surveillance and investigation periodically, treatment of the suspected livestock, vaccination, disinfection, and socialisation. The government needs to control livestock traffic by providing proper regulation. Also, the public might improve knowledge and awareness with their livestock.
\end{abstract}

\section{INTRODUCTION}

Anthrax is one of the zoonotic diseases that is still a global issue since it causes epidemics regularly in a region (1). Anthrax spreads can affect public health, which can also affect the socio-economic aspects and community welfare. In Indonesia, anthrax occurs in several provinces that infect the warm-blooded animals (homoiotherm), namely all vertebrate animals and humans who directly contact anthrax spores (2-3). Anthrax is caused by Bacillus anthracis, which are grampositive stem-shaped bacteria and can form spores (4). Bacillus anthracis will form spores when it falls into dry soil and live for 40 years or more. Transmission of the infection is caused by farm animals eating the grass contaminated with B. Anthracis spores.

Anthrax spreads widely in some countries that become endemic include Saudi Arabia, China, Indonesia, England, Germany, France, and almost all countries on the African continent. Anthrax is an enzootic disease that occurs at a certain time and is usually limited to the endemic area. Based on preliminary studies and the information from Pacitan District Health Office, the prevalence of anthrax in the Pacitan district was 27 cases in 2016 -2020, and it was included as endemic.

Anthrax symptoms in livestock can be categorised into three forms, namely pre-acute, acute and chronic. The per-acute forms are difficult to observe, and acute forms include difficult breathing, fever, body shaking, poor physical condition until unable to stand. The chronic forms usually attack pig herds but rarely in cows, horses, and dogs in which the visible lesions/wounds are limited to the tongue and throat (5). When an infected animal dies, there is usually bleeding in the nose, mouth, anus, and ears (3).

Transmission of anthrax in humans can occur through skin, inhalation, and ingestion/gastrointestinal diseases (6). The Bacillus anthracis enters the human body through lesions on the skin included abrasions, wounds, or insect bites (7). Then, papules will appear within 12-36 hours after infection and grow into vesicles containing liquid and form a vesicle ring (8). Besides that, anthrax spores can be contained in meat that germinated and formed wounds in the intestinal tract. Early symptoms of germinated spores include nausea, 
vomiting blood, abdominal pain, severe diarrhea, and anorexia. Moreover, the infection can occur due to the inhalation of spores from contaminated animal products. The early symptom is similar to colds and can worsen, characterised by the appearance of severe shortness of breath and other symptoms (9).

Indonesia is one of the endemic countries in Asia, whereas the first incidence in humans occurred in Kolaka Regency, Southeast Sulawesi, in 1832, after which anthrax infection was reported to spread throughout the region (10). From 2008 to 2017, seven provinces in Indonesia as endemic areas, such as East Nusa Tenggara Province (NTT), South Sulawesi, East Java, Central Java, West Sulawesi, Gorontalo, and Yogyakarta (11).

In Pacitan, 28 cases were reported from 2016 to 2020. There were sudden deaths of cows and other livestock with symptoms similar to anthrax infection in Donorojo, Pringkuku, and Punung subdistricts in 2016. In the same year, there were clinical symptoms of skin-form Anthrax infecting humans in Pringkuku. In 2017 there were 24 cases of Anthrax with 13 suspects and 8 confirmed. In 2018, three cases of Anthrax were recovered, while in 2019, there were no reports of anthrax cases. In addition, in May 2020, the Pacitan Health Office reported some livestock and goats that died suddenly in the Sobo Pringkuku subdistrict with anus, mouth, and ears emitted fluid and blood. Moreover, one anthrax suspect person displayed a wound on his/her left arm, black wound, and numbness.

Anthrax outbreaks occur during or after heavy rains and contaminate soil, grass, and water (8). In addition to spores, several other factors can be sources of the transmission of anthrax infection both in endemic areas and non-endemic areas. This study aims to analyse the risk factors and transmission sources and visualisation the anthrax-spreading areas in Pacitan.

\section{METHODS}

This type of research was descriptive-analytical that explained cases based on primary and secondary data. The research was conducted in Pringkuku, Pacitan, in May 2020. The primary data was collected from field observations and interviews of farmers whose livestock were reported dead as 41 people and 49 people who followed the measurement of livestock carcasses. Furthermore, swab and serum samples were collected from the anthrax suspect, and soil samples from the cages of the dead animals were collected and tested at the Bogor Veterinary Center. The secondary data was obtained from the information collected through the Pacitan Health Office and Technical Centre for
Environmental Health and Disease Control Surabaya. Data analysis of this study used content analysis techniques that explain the factual state of the community studied and presented in tables, graphs, and figures.

\section{RESULTS}

Cases of livestock deaths in Pacitan were reported in Cemeng Village and Palem Village in Donorejo subdistrict in 2016. In the same year, cow and goat deaths also occurred in Punung and Pringkuku subdistricts, which confirmed positive anthrax. The spread of Anthrax in Pacitan was suspected due to livestock entry from endemic anthrax areas such as Semarang, Sragen, Boyolali, and Wonogiri. The livestock was traded in Pracimantoro Wonogiri Animal Market located nearby Donorojo Subdistrict.

Based on data from the Wates Veterinary Center in early 2016, there were sudden deaths of 8 cows in Cemeng, Donorojo Subdistrict. The dead cows were purchased from Pracimantoro Market, and then the meat was sold to the market. In May 2016, there were also 12 deaths of cows in Gondosari and Tamanasri, Punung Subdistrict. The dead cows in the village were from Giritontro, Wonogiri, in which there were many cases of dead cows.

Table 1. Distribution of the Number of Livestock and Humans with Clinical Symptoms of Anthrax in Pacitan Regency in 2016 and 2020

\begin{tabular}{|c|c|c|c|c|}
\hline \multirow[t]{2}{*}{ Month-Year } & \multirow[t]{2}{*}{ Location } & \multicolumn{2}{|c|}{$\begin{array}{c}\text { Amount of Dead } \\
\text { Livestock }\end{array}$} & \multirow{2}{*}{$\begin{array}{l}\text { Amount } \\
\text { of People } \\
\text { Swabbing }\end{array}$} \\
\hline & & Cow & Goat & \\
\hline $\begin{array}{l}\text { January-February } \\
2016\end{array}$ & $\begin{array}{l}\text { Cemeng village, } \\
\text { Donorojo } \\
\text { Subdistrict }\end{array}$ & 8 & 0 & 0 \\
\hline May 2016 & $\begin{array}{l}\text { Gondosari dan } \\
\text { Tamansari Villages, } \\
\text { Punung Subdistrict }\end{array}$ & 12 & 0 & 0 \\
\hline June 2016 & $\begin{array}{l}\text { Cemeng village, } \\
\text { Donorojo } \\
\text { Subdistrict }\end{array}$ & 3 & 1 & 0 \\
\hline August 2016 & $\begin{array}{l}\text { Pringkuku and } \\
\text { Sobo Village, } \\
\text { Pringkuku } \\
\text { Subdistrict }\end{array}$ & 1 & 0 & 0 \\
\hline April-May 2020 & $\begin{array}{l}\text { Sobo Village, } \\
\text { Pringkuku } \\
\text { Subdistrict }\end{array}$ & 3 & 14 & 1 \\
\hline
\end{tabular}

Table 2. Results of Laboratory Examination for Anthrax in Pacitan Regency in 2020

\begin{tabular}{lcc}
\multicolumn{1}{c}{ Test Type } & $\begin{array}{c}\text { Amount of } \\
\text { People }\end{array}$ & Result \\
\hline Human Swab & 1 & Positive Anthrax \\
\hline Soil sampling test & 0 & Positive Anthrax \\
\hline
\end{tabular}

In June 2016, farmers from Jelok sub-Village, Cemeng Village, Donorojo District also bought cows from Pracimantoro Market, Wonogiri. The cows were placed in a cage nearby the goat pen. A few days later, 
one of the cows was sick with clinical symptoms similar to the anthrax infection. Then, the sick cow was sold on butchers in Pringkuku Village, Pringkuku Subdistrict for forced slaughter in which the meat and offal were sold at Pringkuku, Punung, and Ngadireja Market. Meanwhile, other cows and goats that died were buried in the yard.

In August 2016, there was also the death of cows in Sobo, belonging to the livestock group in Pringkuku that did not show pain symptoms and had a normal appetite as usual. However, the cow was found dead with flatulence and fresh bleeding from the nose. In addition, some clinical symptoms of skin-form anthrax disease were reported that four people were infected in Pringkuku Subdistrict. Three infected people in May 2016 have recovered, and one infected person in June 2016 has not fully recovered after being treated at the Public Health Center. The four people were concluded as suspected anthrax after handling cows at the slaughterhouse in Pringkuku.

In April-May 2020, deaths of 3 cows and 14 goats were reported with clinical symptoms of sudden death and bleeding in their anus, mouth, and ears. Based on the investigation, one person has suspected anthrax because he had a wound on the left arm. Furthermore, 41 people had contact with suspected, and from 49 people who helped to deal with the carcasses of dead animals, they were declared healthy. Swab and serum specimens on the suspects and soil samples in the cages of the dead animals reported positive anthrax.

Based on the Pacitan District Health Office profile, anthrax cases between 2016-2020 in Pacitan district occurred at the beginning of the year (JanuaryMay), and the entire Pacitan district was experiencing a rainy season with an average rainfall around 201-300 $\mathrm{mm}$. Meanwhile, a Central Bureau of Statistics database showed that Pringkuku is a mountainous area with a slope between $5^{0}-15^{0}$ from the land. Thus, the location of the house differs in height between the residents.

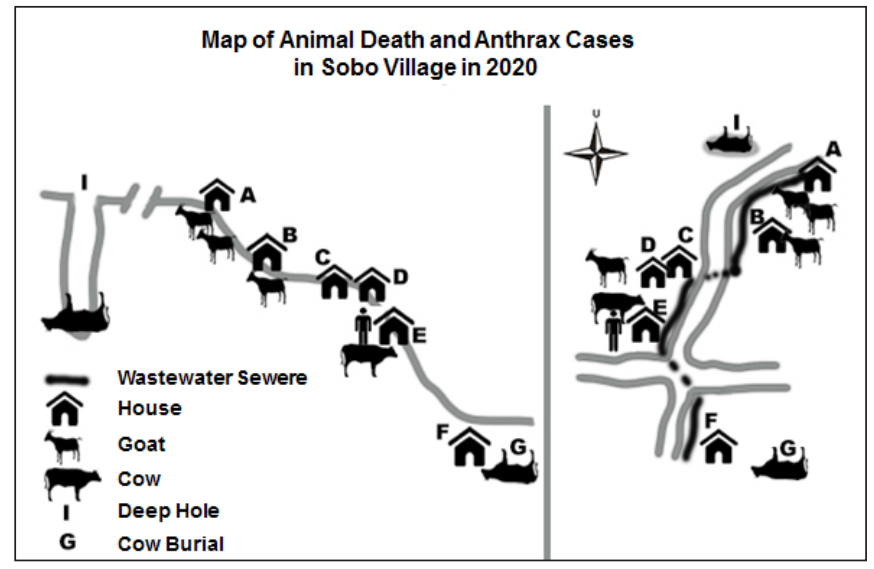

Figure 1. Map of Animal Death and Anthrax Cases in Sobo Village in 2020
The mapping of the dead livestock in Sobo (figure 1) shows that the animal cages in Sobo were close to the farmer's house, and some cages were in the front yard. In addition, the house location of the owner of the dead animals ( $A, B, C, D, E$, and F) had different elevations. Observations from the exiled cage sewage sewer flow, there was a connection from $A$ to $F$ locations. The three locations (A, C, D) were places of the dead livestock cases in 2016. Meanwhile, the other three locations $(B, E$, and $F$ ) were places of the dead livestock cases in 2020.

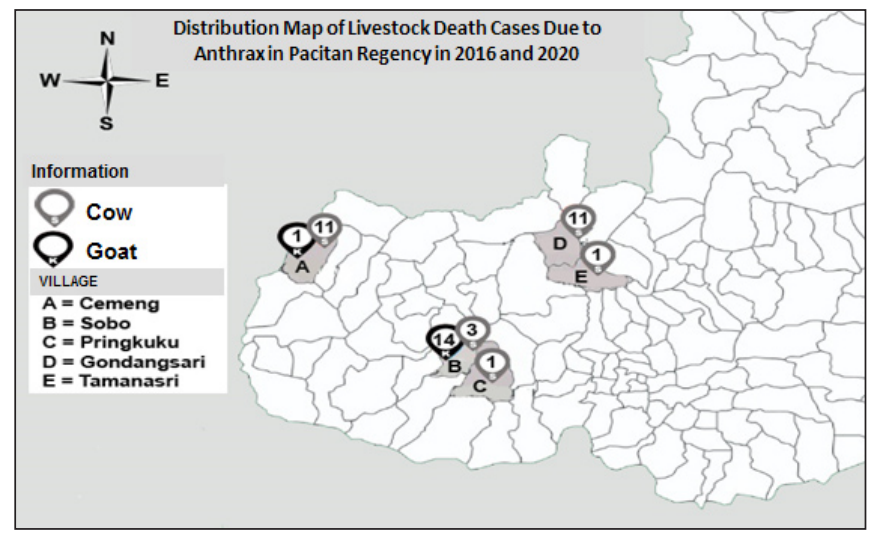

Figure 1. Distribution Map of Livestock Death Cases Due to Anthrax in Pacitan Regency in 2016 and 2020

Additionally, at house $\mathrm{E}$, there was one person who suffered anthrax disease in 2020 . The dead livestock was dumped in the wells/caves called luweng as shown in figure 2 (the holes in the ground look like cave shapes). The luweng has located about $1 \mathrm{~km}$ from the community settlement in the middle of the forest. The depth of the luweng was about 15-20 meters, and at the bottom was the underground water stream. The dead animals were being thrown away without any special treatment. The residents in the area reported that it was usual to dump the dead animals in the location. The location of $G$ was the yard of farmer $F$ in which it was used to bury his dead livestock. The burial process was also without using the standard treatment for animals affected by anthrax.

\section{DISCUSSION}

Anthrax is an endemic disease and tends to occur repeatedly. People who have greater risks of contracting anthrax include animal breeders, farmers, slaughter, or other jobs related to animals contact (5). Based on field observations, the number of anthrax sufferers who died in 2016 was four people as animals slaughter. In 2020, one sufferer was the owner of a cow that died due to anthrax.

Based on data from the Central Bureau of Statistics, most people in Pringkuku are farmers who have livestock kept in a cage close to their house (12). 
Therefore, it is important to enhance awareness of the risk of reoccurrence of anthrax disease, especially in the areas where cases of dead animals have occurred. They should have adequate knowledge about anthrax infection. Based on the interviews with people at the Pacitan District Livestock and Agriculture Service, people in Sobo Pringkuku District refused to vaccinate their livestock even though dozens died suddenly. They thought that vaccination killed their livestock. Livestock vaccination is one of the efforts to prevent transmission and reinfection from anthrax transmission (13). It is reported that vaccination in the last two years has significantly reduced anthrax in the cattle (OR = $0.014 ; 95 \%)(14)$.

In 2016, many farmers sold their sick cows or goats in the market even though the cow confirmed positive anthrax, based on the laboratory test from Wates Center for Veterinary Medicine. Afterward, four people confirmed positive anthrax infection. Anthrax infection occurs due to close contact with anthrax spores. The process of slaughtering infected animals or improper handling of animals carcasses can cause anthrax bacteria to escape from the body of livestock and contaminate the soil and plants in the area (15).

Suspicion of anthrax spores in the soil in the area related to the anthrax incidence in 2016, the lack of public knowledge about handling animal carcasses that died suddenly in 2016 resulted in the possibility of spreading anthrax spores in the soil. In addition, Bacillus anthracis spores are resistant to extreme environmental conditions (16) and can survive in polluted soil, air, water, and plants for a long time (17). Moreover, these bacteria can form spores when the environment has sufficient oxygen levels. The incubation period for Anthrax is about 1 - 3 days, but in some cases, it can last until 20 days (5).

Anthrax bacterial spores can survive in the soil for a very long time and are widely found in certain areas with high rainfall, calcareous soil, and rich in organic material (18). Incidence of anthrax can repeatedly occur in endemic areas and during the rainy season (19). Anthrax infection often occurs at the beginning of the rainy season, when grass for fodder is growing. This situation makes livestock contact with spores in the soil through grass feed (20). The study in China states a significant correlation between rainfall and anthrax cases in the community with a correlation coefficient of 0.67 and $\mathrm{Cl}=0.54-0.78(21)$.

Another environmental factor as a risk factor for anthrax transmission is the topography of mountainous areas with slopes of the land. Based on the results of observations of dead animals with indications of Anthrax in 2020, the incident started from the farmer's house in the highest land area. Then, $1-2$ weeks later, sequentially to the farmer's house was located in the lower area. The land slope factor was also strengthened by the flow of sewer that connected each house from top to bottom. Based on the interviews and observations, the farmers in Sobo have some habits of cleaning the cages and livestock manure regularly. The period for cleaning the cage depends on the number of livestock and the pile of manure. Cage cleaning is carried out once a year, or at any time, likely livestock and manure sold out, or buy new livestock.

The habit of accumulating animal waste for a long time increases the risk of spreading anthrax spores (22), which can be carried away by rainwater flowing from higher areas to lower areas. Underground water can lead to a buildup of anthrax spore concentrations in lowland areas. In our study area, luweng, which is used to dispose of dead animal carcasses, can be a place to transit anthrax spores and can be dangerous if there is underground water flow in it. Anthrax spores have hydrophobic properties, which cause the spores to be carried away by rainwater. The density of spores in the soil will increase when water evaporation occurs, and the area will become a place for excessive anthrax spore development (11).

The study in Boyolali showed a significant correlation between high and low places with anthrax cases in the community ( $p=0.001$ and $r=-0.864$ ) with a negative direction and very strong correlation (11). The negative direction means that the area with a lower altitude can increase the incidence of anthrax in the community. Another study in Kazakhstan also states a relationship between the height area and anthrax cases with $p=0.001$.

Based on the previous discussion, the risk factors for the incidence of Anthrax in Pacitan Regency in 2016 and 2020 include 1) mobilization of livestock from endemic areas; 2) the low level of public knowledge about anthrax, such as people to slaughter sick animals with symptoms similar to anthrax before the animal dies and the meat is sold in the market, handling of animal carcasses buried in the yard of the house or dumped in the luweng, and refusal to vaccinate animals; and 3) topographical factors, namely the slope of the land.

Some efforts to control Anthrax in Indonesia are often carried out when anthrax incidence have attacked and entered the community (5). Anthrax tends to recur in an area, and then it becomes endemic in that area. Spores of anthrax bacteria can long survive in suitable environmental conditions, and the spores 
can be reactivated (23). Anthrax controlling cannot be carried out at once requires regular monitoring activities (3) comprehensively by all parties, starting by local governments involving related agencies (sectors of animal husbandry, agriculture, health and markets, and village officials), the community, and the livestock trade business.

Early warning systems in endemic areas are needed to prevent the recurrence of anthrax cases and to break of anthrax transmission, namely: 1) livestock regular vaccination activities and monitoring that carried out by the Department of Agriculture and Livestock; 2) education on the anthrax epidemiology, risk factors for anthrax transmission, and how to handle sick or dead livestock with anthrax symptoms by procedures (24); 3) tiered reporting system starting from the village, animal nurse, public health center, and related agencies; and 4) active surveillance on breeders and livestock (5).

Prevention of anthrax transmission should also be carried out in areas directly closest to the endemic areas. Socialisation about anthrax infection also can be carried out toward policymakers and communities that are still declared free of anthrax to ensure control measurement, including minimizing the livestock traffic and their products, especially those from endemic areas. Vaccinations for all livestock, establishing sites to control anthrax's spread and increasing preparedness at slaughterhouses (15).

The Pacitan Health Service and the Livestock Agriculture Service should routinely conduct education regarding anthrax disease and strengthen synergy from many sectors. When public knowledge increases, it is hoped that the community can lead a clean and healthy lifestyle to avoid contamination of anthrax spores and the breeders have the awareness to vaccinate their livestock. In addition, they strengthened the micro-Penta helix concept in the village community, starting with Village Government officials, the community and breeders, academics, livestock trading business persons, and the media to achieve their commitment.

\section{ACKNOWLEDGEMENTS}

Researchers would like to thank BBTKLPP Surabaya and the Pacitan District Health Office for supporting this research.

\section{CONCLUSION}

The risk factors for anthrax transmission in 2016 and 2020 are the incidence of livestock traffic from endemic anthrax areas, lack of knowledge about anthrax disease, and the region's topography. The measurement of the anthrax control that is carried out routinely includes surveillance and investigation of infectious animal diseases, treatment of suspected anthrax, vaccination, disinfection, and education.

Some recommendations that can be given to control the anthrax incidence in Pacitan Regency include 1) routine counseling to farmers, breeders, and community to enhance implementation of clean and healthy living behavior, 2) establishment of anthrax cadres in villages to increase community participation for strengthening early detection and reporting systems, 3) training for health service workers, farmers, and the community in regard with management synergy of anthrax, 4) vaccination of livestock and disinfection of the cage environment regularly, 5) strict surveillance on livestock and the community.

\section{REFERENCES}

1. Olani A, Dawo F, Lakew M. Laboratory Diagnostic Methods and Reported Outbreaks of Anthrax in Ethiopia. Eur J Biol Res. 2020;10(2):81-95. https:// zenodo.org/record/3773896\#.YL-AhtszblU

2. Yadeta W, Jilo K. Recent Understanding of the Epidemiology of Animal and Human Anthrax in Ethiopia with Emphasis on Diagnosis , Control and Prevention Interventions- Review. World J Med Sci. 2020;17(1):1-9. https://doi. org/10.1155/2020/1295381

3. Martindah E. Risk Factors, Attitude and Knowledge of Farmers in Controlling Anthrax. Indones Bull Anim Vet Sci. 2018;27(3):135-144. https://doi. org/10.14334/wartazoa.v27i3.1689

4. Pilo P, Frey J. Pathogenicity, Population Genetics and Dissemination of Bacillus Anthracis. Infect Genet Evol. 2018;64(1):115-125. https://doi. org/10.1016/j.meegid.2018.06.024

5. Ministry of Agriculture of Republic Indonesia. Guidelines for Control and Eradication of Infectious Animal Diseases (PHM)-Anthrax Disease Series. 2016. http://luk.tsipil.ugm.ac.id/artikel/kesehatan/ KementanAnthrax.pdf

6. Mwakapeje ER, Assenga JA, Kunda JS, Mjingo EE, Makondo ZE, Nonga HE, et al. Prevention, Detection, and Response to Anthrax Outbreak in Northern Tanzania using One Health Approach: A Case Study of Selela Ward In Monduli District. Int J One Heal. 2017;3(1):66-76. https://doi. org/10.14202/IJOH.2017.66-76 
7. Zuyina I, Sari R, Apriliana S. Gambaran Umum , Prevalensi, dan Pencegahan Antraks pada Manusia di Indonesia General Description, Prevalence, and Prevention of Human Anthrax in Indonesia. BALABA. 2020;16(2):135-148. https:// doi.org/10.22435/blb.v16i2.3401

8. Clarasinta C, Soleha TU. Penyakit Antraks : Ancaman untuk Petani dan Peternak. Majority. 2017;7(1):158-164. https://juke.kedokteran.unila. ac.id/index.php/majority/article/view/1763

9. Specialist of Childern Health Universitas Airlangga. Modul, PPK, dan Rekomendasi Divisi Ilmu Kesehatan Anak, Penyakit Antrax. Surabaya: Universitas Airlangga; 2017. http://spesialis1.ika. fk.unair.ac.id/wp-content/uploads/2017/03/TI20 Anthax-Q.pdf

10. Suardana W. Penyakit Menular dari Hewan ke Manusia. Yogyakarta: PT Kanisius Yogyakarta; 2015. 89 p.

11. Abawi I, Fibriana Al. Analisis Spasial Faktor Lingkungan Fisik Daerah Endemik Antraks. Higeia. 2019;3(2):190-201. $\quad$ https://doi.org/10.15294/ higeia.v3i2.25478

12. Central Bureau of Statistics. Livestock Population by District and Type of Livestock in Pacitan Regency. Pacitan: Central Bureau of Statistics; 2018. https:// pacitankab.bps.go.id/statictable/2018/11/06/162/ populasi-ternak-menurut-kecamatan-dan-jenisternak-di-kabupaten-pacitan-2017.html

13. Ministry of Health of Republic Indonesia. Handbook of Investigation and Management of Extraordinary Events of Infectious Diseases and Food Poisoning. Jakarta: Ministry of Health of Republic Indonesia; 2011. https://www.dinkes. pulangpisaukab.go.id/2018/09/20/buku-pedomanpenyelidikan-dan-penanggulangan-kejadian-luarbiasa-pedoman-epidemiologi-penyakit-penyakitmenular-dan-keracunan-pangan-edisi-revisi-tahun-2017I

14. Rao S, Traxler R, Napetavaridze T, Asanishvili Z, Rukhadze K, Maghlakelidze G, et al. Risk Factors Associated with the Occurrence of Anthrax Outbreaks in Livestock in the Country of Georgia: A Case-Control Investigation 2013-2015. PLoS One. 2019;14(5):1-16. https://doi.org/10.1371/journal. pone.0215228

15. Beganda I, Dariani W, Yudianingtyas DW. Investigasi Outbreak Penyakit Antraks di Kabupaten Polewali
Mandar Tahun 2016. In Proceedings of the 20th FAVA \& the 15th KIVNAS PDHI Hemera Zoa. 2018;(1):385-389. https://jurnal.ipb.ac.id/index. php/hemera/article/view/23761

16. Hoffmann C, Zimmermann F, Biek R, Kuehl H, Nowak K, Mundry R, et al. Persistent Anthrax as a Major Driver of Wildlife Mortality in a Tropical Rainforest. Nature. 2017;548(7665):82-85. http:// dx.doi.org/10.1038/nature23309

17. Juwita S, Purwanta P, Muflihanah M, Djatmikowati TF. Identification of Anthrax in Endemic Areas in South Sulawesi Province. J Ris Vet Indones. 2018;2(2):50-55. https://doi.org/10.20956/jivi. v2i2.4423

18. iSIKHNAS. Manual Penyakit Hewan Mamalia, Penyakit Anthraks. Jakarta: iSIKHNAS; 2015. p. 119-32. http://wiki.isikhnas.com/images/a/a1/ Penyakit_Anthrax.pdf

19. Parthiban S. Anthrax: A Re-Emerging Livestock Disease. Int J Nutr Food Sci. 2015;4(4):7. https:// doi.org/10.11648/.ijnfs.s.2015040401.12

20. Basri C, Dwidzuriputra AS, Sudarnika E. Factors Influencing Farmers Participation in the Vaccination Program against Anthrax in Bogor District, Indonesia. ACTA Vet Indones. 2019;29-34. https:// doi.org/10.29244/avi.0.0.29-34

21. Chen WJ, Lai SJ, Yang Y, Liu K, Li X Lou, Yao $\mathrm{HW}$, et al. Mapping the Distribution of Anthrax in Mainland China, 2005-2013. PLoS Negl Trop Dis. 2016;10(4):2005-2013. https://doi.org/10.1371/ journal.pntd.0004637

22. Finke E-J, Beyer W, Loderstädt U, Frickmann H. Review: The Risk of Contracting Anthrax from SporeContaminated Soil - A Military Medical Perspective. Eur J Microbiol Immunol. 2020;10(2):29-63. https:// doi.org/10.1556/1886.2020.00008

23. Kholilullah ZA, Massi MN, Muslimin L, Sjahril R. Identification of Virulence of Bacillus Anthracis from Soil by Multiplex PCR Technique in The South Sulawesi Province of Indonesia. Am J Infect Dis Microbioogy. 2016;4(6):118-122. http://www. sciepub.com/AJIDM/content/4/6

24. Apriliana UI, Suryanto BR, Handoko A. Anthrax: Emerging and Re-Emerging Diseasis Di Kabupaten Pacitan, Provinsi Jawa Timur. Balai Besar Veteriner Wates. 2017;17(1):21-31. http://bbvetwates. ditjenpkh.pertanian.go.id/content/buletin/ anthrax_emerging_and_reemerging_diseasis di_kabupaten_pacitan_provinsi_jawa_timur 